\title{
Evaluating soil organic carbon sequestration potential in the Cotton Belt with the soil conditioning index
}

\author{
A.J. Franzluebbers, M.D. Hubbs, and M.L. Norfleet
}

\begin{abstract}
Simulation models that are sensitive to management, edaphic factors, and climate could provide insights into how land owners and producers might be able to sequester soil organic carbon (C) and engage in emerging carbon markets. In this study, the soil conditioning index (SCI) embedded in the Revised Universal Soil Loss Equation (RUSLE2) model was used to predict (1) potential soil organic C sequestration under conventional and conservation management of a diversity of cotton cropping systems throughout the Cotton Belt and (2) relative influences of soil texture, slope, climatic conditions, and management on potential soil organic C sequestration. Across 10 regions of the Cotton Belt, SCI scores ranked in the following order: perennial pasture $>$ no-till cropping systems $>$ conventional tillage cotton. Variations in significance of SCI scores occurred among 5 different no-till cropping systems within regions of the Cotton Belt. For example, 7 of the 10 regions had significantly ( $p \leq$ $0.05)$ greater SCI scores (linked to greater soil organic C sequestration) when monoculture cotton was grown with winter cover crop than without. Variation in SCI was dominated by management $(46 \%)$ and slope $(24 \%)$ and very little affected by climate $(7 \%)$ and soil texture $(1 \%)$. Increasingly wetter climatic conditions (as expressed by increasing precipitation to potential evapotranspiration) had a negative influence on SCI scores for all management systems and land slopes evaluated, but particularly for moldboard-plowed cotton on sloping land. With a linear relationship between SCI and soil organic C sequestration, predicted soil organic C sequestration averaged $-0.31 \pm 0.19 \mathrm{Mg} \mathrm{C} \mathrm{ha}^{-1} \mathrm{y}^{-1}\left(-280 \pm 170 \mathrm{lb} \mathrm{ac}^{-1} \mathrm{yr}^{-1}\right)$ under conventionally tilled cotton, $0.12 \pm 0.06 \mathrm{Mg} \mathrm{C} \mathrm{ha}^{-1} \mathrm{y}^{-1}\left(103 \pm 52 \mathrm{lb} \mathrm{ac}^{-1} \mathrm{yr}^{-1}\right)$ under various no-till crop rotations, and $0.26 \pm 0.02 \mathrm{Mg} \mathrm{C} \mathrm{ha}^{-1} \mathrm{y}^{-1}\left(231 \pm 20 \mathrm{lb} \mathrm{ac}^{-1} \mathrm{yr}^{-1}\right)$ under perennial pasture. Cotton production with conventional tillage could only be expected to maintain soil organic $\mathrm{C}$ under a best-case scenario and would lose substantial soil organic $\mathrm{C}$ under most other scenarios. Simulations showed the strong, positive influence that conservation agricultural management has to sequester soil organic $\mathrm{C}$, irrespective of climate, slope, and texture.
\end{abstract}

Key words: climate — conservation tillage — cover cropping — crop rotation-modeling

Conservation agricultural management is known to increase surface soil organic matter content in degraded cropland throughout the southeastern United States (Rhoton 2002; Terra et al. 2005; Spargo et al. 2008; Novak et al. 2009) and elsewhere (Madejon et al. 2009; Sá et al. 2009; Du et al. 2010; Salvo et al. 2010). Some key conservation approaches that have consistently increased soil organic carbon (C) are conservation tillage (no-till, strip tillage, reduced tillage, etc.) (Franzluebbers et al.1998; 1999), diverse crop rotations and decreasing periods of bare fallow (Franzluebbers and
Modeling of soil organic C sequestration could help to understand how soil type, cropping system, soil management, and climatic conditions influence results. In a comparison of cotton management systems simulated on soils in three different Major Land Resource Areas in the southeastern United States, both the Environmental Policy Integrated Climate (EPIC) model and the soil conditioning index (SCI) predicted that no-till management of cropland would lead to significant sequestration of soil organic C compared with conventional tillage management (Abrahamson et al. 2007). In addition, the SCI predicted that more diverse crop rotations would sequester a greater amount of soil organic $\mathrm{C}$ than monoculture cotton. The SCI was positively related to soil organic C simulated by EPIC from a total of six sites in the region (Abrahamson et al. 2009). More recently, SCI was calibrated against actual soil organic C content measured in several medium- and long-term field studies in the southeastern United States. The simple linear calibration of data suggests that for every unit increase in SCI, soil organic $\mathrm{C}$ sequestration will increase $0.25 \mathrm{Mg} \mathrm{C} \mathrm{ha} \mathrm{y}^{-1} \mathrm{y}^{-1}(223 \mathrm{lb} \mathrm{C}$ $\mathrm{ac}^{-1} \mathrm{yr}^{-1}$ ) (Franzluebbers et al. 2011a). There are indications that a nonlinear calibration might also be appropriate, such that at positive SCI scores the increase in soil organic C should be greater than at negative SCI scores (Abrahamson et al. 2007, 2009; Franzluebbers et al. 2011a).

The SCI is a component of the Revised Universal Soil Loss Equation (RUSLE2), a model containing both empirical and process-based science to predict erosion from rainfall and runoff (USDA NRCS 2010). In most states, the USDA Natural Resources Conservation Service currently uses the SCI to help determine eligibility of conservation payments for the adoption of conservation tillage in programs such as Environmental Quality Incentive Program and Conservation Stewardship Program. Typically, a positive cover cropping (Sainju et al. 2002; Franzluebbers 2005), and rotation of annual crops with perennial forages (Studdert et al. 1997; Franzluebbers and Stuedemann 2008; Ernst and Siri-Prieto 2009). Unfortunately though, the magnitude of soil organic C sequestration still appears to be variable, even within similar soils, sites, and environmental conditions, such that several-fold differences in soil organic $\mathrm{C}$ sequestration have been observed when comparing results from across a region (Franzluebbers 2010).
Alan J. Franzluebbers is an ecologist at the Plant Science Research Unit of the USDA Agricultural Research Service in Raleigh, North Carolina. Michael D. Hubbs is director of the Financial Assistance Program Division of the USDA Natural Resources Conservation Service in Washington, DC. M. Lee Norfleet is a soil scientist at the Blacklands Research Center of the USDA Natural Resources Conservation Service in Temple, Texas. 


\section{Table 1}

Characteristics of cotton production in each of the 10 different regions of the Cotton Belt from the 2007 Census of Agriculture (USDA NASS 2010). Data for farm characteristics (number of counties, number of farms, land in cotton, and irrigated land) were from 2007 and only if land area in cotton was reported for a county. Land in cotton (ha farm ${ }^{-1}$ ) was mean \pm standard deviation among county-level values in 2007 . Cotton, corn, peanut, soybean, and wheat yields were mean \pm standard deviation among county-level values for 2002 and 2007 combined. Regions were defined from RUSLE2 crop management zones (Desert Southwest = 23, 33, 34, and 43; Southern High Plains = 5, 15, and 19; South Texas = 37.1, 38.1, 41, 44, 57, and 58; Central Rolling Plains = 40 and 48; Lower Mississippi Valley = 37 and 38; Upper Mississippi Valley = 17 and 42; Central Coastal Plain = 69; Tennessee Valley $=63$; Eastern Coastal Plain $=67$; and Southern Piedmont $=66$ ).

\begin{tabular}{|c|c|c|c|c|c|c|c|c|c|c|c|}
\hline Characteristic & \multicolumn{11}{|c|}{ Region of Cotton Belt } \\
\hline Number of counties & 28 & 41 & 49 & 55 & 33 & 36 & 31 & 44 & 130 & 22 & 469 \\
\hline Number of farms & 1,428 & 4,105 & 1,828 & 1622 & 893 & 1,854 & 818 & 1,216 & 4,367 & 211 & 18,605 \\
\hline Land in cotton (million ha) & 0.30 & 1.22 & 0.36 & 0.36 & 0.20 & 0.65 & 0.12 & 0.29 & 0.68 & 0.03 & 4.25 \\
\hline Irrigated land (\%) & 97 & 46 & 12 & 19 & 26 & 70 & 5 & 3 & 19 & 1 & 38 \\
\hline Cotton yield (bales ha-1) & $6.5 \pm 1.3$ & $4.1 \pm 1.0$ & $3.7 \pm 1.0$ & $3.0 \pm 0.9$ & $4.3 \pm 0.4$ & $4.7 \pm 0.6$ & $2.7 \pm 0.6$ & $3.3 \pm 0.7$ & $3.2 \pm 0.8$ & $2.7 \pm 1.0$ & $3.6 \pm 1.3$ \\
\hline Corn yield (Mg ha-1) & $11.0 \pm 1.9$ & $10.9 \pm 1.7$ & $5.2 \pm 1.4$ & $7.5 \pm 2.5$ & $8.4 \pm 0.9$ & $9.3 \pm 1.1$ & $4.6 \pm 1.2$ & $6.6 \pm 0.9$ & $6.0 \pm 1.8$ & $4.3 \pm 1.5$ & $6.9 \pm 2.5$ \\
\hline Peanut yield $\left(\mathrm{Mg} \mathrm{ha}^{-1}\right)$ & 3.4 * & $3.8 \pm 0.5$ & $1.8 \pm 1.3$ & $3.2 \pm 0.8$ & $4.1 \pm 0.5$ & $1.9 \pm 0.5$ & $2.8 \pm 0.5$ & $1.5 \pm 1.5$ & $2.9 \pm 0.6$ & 2.2 * & $2.9 \pm 0.8$ \\
\hline Soybean yield $\left(\mathrm{Mg} \mathrm{ha}^{-1}\right)$ & 2.7 * & $2.6 \pm 0.6$ & $1.8 \pm 0.4$ & $1.9 \pm 0.9$ & $2.2 \pm 0.2$ & $2.1 \pm 0.2$ & $1.7 \pm 0.4$ & $1.6 \pm 0.3$ & $1.5 \pm 0.4$ & $1.2 \pm 0.3$ & $1.7 \pm 0.5$ \\
\hline
\end{tabular}

* Only one county reporting crop yield.

SCI value allows eligibility, and a negative SCI value does not. The SCI is a relatively simple function of three components known to affect SOC: organic material (OM) grown on or added to soil, field operations (FO) that alter organic material placement in the soil profile and that stimulate organic matter breakdown, and erosion (ER) that removes and sorts surface soil organic matter (sheet, rill, or wind erosion, but not concentrated flow erosion, such as ephemeral or gully erosion) (USDA NRCS 2003).

Reliable information on soil organic C sequestration is urgently needed to provide scientific justification and foster practical guidance for the nascent $\mathrm{C}$ market. Simulations with SCI could provide reasonable projections of how various conservation management systems might affect soil organic $\mathrm{C}$ sequestration and soil quality. Because of its relatively simple modeling approach and widespread use with the USDA Natural Resources Conservation Service, the SCI could become a jumpstart approach to engage farmers and $\mathrm{C}$ market traders for immediate benefit to the agricultural community and the environment.

Now that the SCI has been quantitatively calibrated against long-term soil organic C sequestration in the southeastern United States (Franzluebbers et al. 2011a) and in the Midwest (Franzluebbers et al. 2011b), the purpose of this study was to (1) estimate potential soil organic $\mathrm{C}$ sequestration using
SCI scores under conventional and conservation management of a diversity of cotton cropping systems throughout the Cotton Belt and (2) evaluate the relative influences of soil texture, slope, climatic conditions, and management on SCI scores.

\section{Materials and Methods}

Model simulations were conducted for locations throughout the Cotton Belt of the southern United States using RUSLE2 (USDA NRCS 2010). The RUSLE2 model calculates SCI as a function of three components:

$\mathrm{SCI}=\mathrm{OM} \times 0.4+\mathrm{FO} \times 0.4+\mathrm{ER} \times 0.2$

where OM is organic matter, FO is field operations, and ER is erosion (USDA NRCS 2003).

In Analysis 1, counties with land harvested for cotton in 2007 were selected for simulation ( $n=469$ counties) using the 2007 Census of Agriculture (USDA NASS 2010) County-specific climate and crop yield data and a randomly selected soil type were used for each simulation. Crop yield was the mean county yield in 2002 and 2007 for each crop (table 1).As a neutral selection procedure, soil type was selected by matching the numeric listing of alphabetically arranged counties within a state with the numeric listing of soil types in RUSLE2. Slope of land (maximum allowed of $15 \%$ ) was determined by the soil type selected. Irrigation was included in the simulation based on the percentage of cotton land irrigated in a county. Four levels of irrigation were classified ( $0 \%$ to $25 \%$ of land irrigated $=$ no irrigation [rainfed], $25 \%$ to $50 \%$ of land irrigated $=178 \mathrm{~mm} \mathrm{[7} \mathrm{in]} \mathrm{of} \mathrm{irri-}$ gation applied per cash crop, $50 \%$ to $75 \%$ of land irrigated $=355 \mathrm{~mm}$ [14 in] of irrigation applied per cash crop, and $75 \%$ to $100 \%$ of land irrigated $=533 \mathrm{~mm}$ [21 in] of irrigation applied per cash crop). Soil characteristics, slope, crop yields, and irrigation regime selected for each county-specific observation can be found in Appendix A (found online at http://www.gaswcs.org/uploads/ GASWCS/JSWC_Appendix_A.pdf). A set of seven standard cropping systems was simulated in each county:

1. Conventional tillage continuous cotton (CT-c, 1-year rotation)

2. No-till continuous cotton (NT-c, 1-year rotation)

3. No-till continuous cotton with winter wheat cover crop (NT-cc, 1-year rotation)

4. No-till cotton-cotton-peanut-corn rotation with winter wheat cover crop (NT-ccpc, 4-year rotation)

5. No-till cotton-corn-wheat/soybean rotation with winter wheat cover crop (NT-ccws, 3-year rotation)

6. No-till cotton-cotton-clover/grass hay-grass pasture-corn rotation with winter wheat cover crop (NT-cchpc, 5-year rotation) 


\section{Figure 1}

Geographic distribution of cotton production in the United States (USDA NASS 2002). Cotton Belt regions are Desert Southwest (DSW), Southern High Plains (SHP), South Texas (STX), Central Rolling Plains (CRP), Lower Mississippi Valley (LMV), Upper Mississippi Valley (UMV), Central Coastal Plain (CCP), Tennessee Valley (TNV), Eastern Coastal Plain (ECP), and Southern Piedmont (SOP).

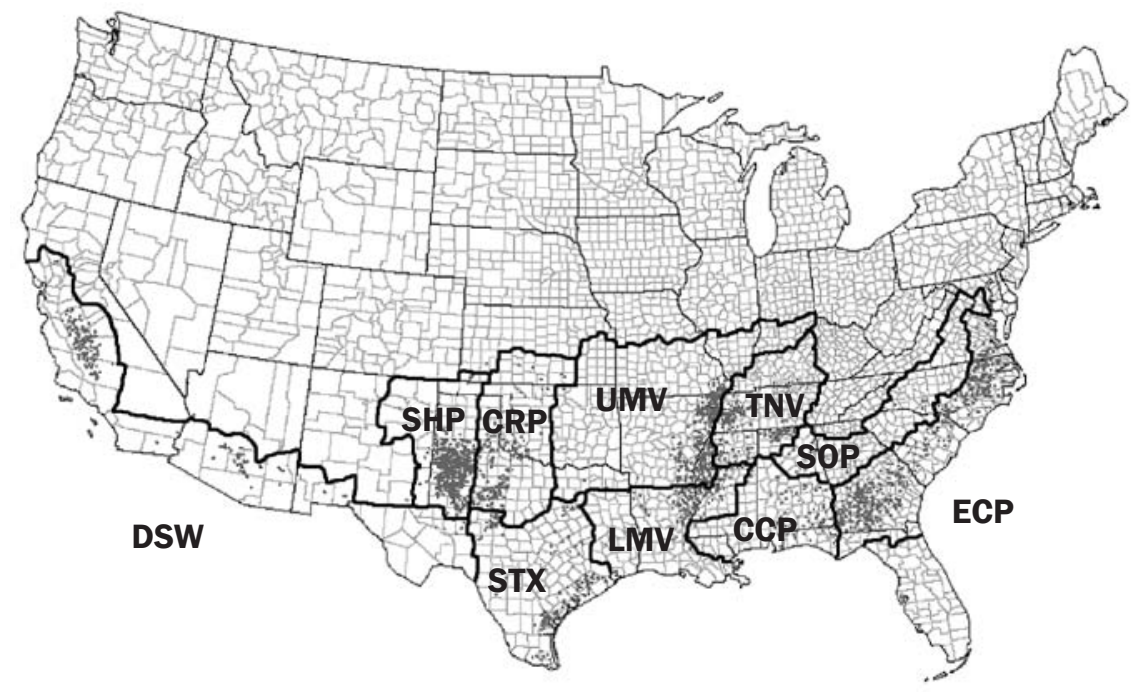

7. Perennial warm-season pasture with rotational grazing (PP, 10-year rotation)

Counties were grouped into 10 broad regions (figure 1), which spanned one or more crop management zones (CMZ) delineated within RUSLE2:

- DSW-Desert Southwest (CMZ 23, 33, 34 , and 43), $\mathrm{n}=28$ counties

- SHP-Southern High Plains (CMZ 5, 15, and 19), $\mathrm{n}=41$ counties

- STX - South Texas (CMZ 37.1, 38.1, 41, 44, 57, and 58), $\mathrm{n}=49$ counties

- CRP-Central Rolling Plains (CMZ 40 and 48), $\mathrm{n}=55$ counties

- LMV-Lower Mississippi Valley (CMZ 37 and 38), $\mathrm{n}=33$ counties

- UMV-Upper Mississippi Valley (CMZ 17 and 42$), n=36$ counties

- CCP-Central Coastal Plain (CMZ 69), n $=31$ counties

- TNV-Tennessee Valley (CMZ 63), $n=44$ counties

- ECP-Eastern Coastal Plain (CMZ 67), n $=130$ counties

- SOP-Southern Piedmont (CMZ 66), $\mathrm{n}=22$ counties

Characteristics of cotton production and other crop yields in these 10 regions can be found in table 1. Orthogonal contrasts were constructed within an analysis of variance to test for the following effects:
- Conventional vs. conservation systems (Cropping System 1 [CT-c] vs. all others)

- Cropping vs. grass (Cropping Systems 2 through 6 [NT-c, NT-cc, NT-ccpc, NT-ccws, and NT-cchpc] vs. Cropping System 7[PP])

- Monoculture vs. rotated cotton (Cropping Systems 2 and 3 [NT-c and NT-cc] vs. Cropping Systems 4 through 6 [NT-ccpc, NT-ccws, and NT-cchpc])

- With vs. without cover cropping in monoculture cotton (Cropping System 2 [NT-c] vs. Cropping System 3 [NT-cc])

- Cotton once in three years vs. more often (Cropping System 5 [NT-ccws] vs. Cropping Systems 4 and 6 [NTccpc+NT-cchpc])

- Cotton rotated with peanut vs. rotated with grass (Cropping System 4 [NT-ccpc] vs. Cropping System 6 [NT-cchpc])

In Analysis 2, separate simulations were run to assess the relative variations in SCI and soil loss in response to a set of four factors with three levels each: (a) slope (1\%, 5\%, and 9\%), (b) soil texture (gradient of three clay concentrations specifically available within each region), (c) management system (gradient of three disturbance regimes defined broadly as conventional tillage, reduced tillage, and no-till), and (d) climate (gradient of three climatic conditions defined by precipitation and temperature). Details of the simulation conditions can be found in table 2 .

In Analysis 3, separate simulations were also run to understand the potential interactions among climatic conditions $\left(12.8^{\circ} \mathrm{C}\right.$ to $22.7^{\circ} \mathrm{C}\left[55^{\circ} \mathrm{F}\right.$ to $73^{\circ} \mathrm{F}$ ] mean annual temperature and 224 to $1500 \mathrm{~mm}$ [9.5 to 59.1 in] mean annual precipitation), slope ( $1 \%$ and $5 \%$ ), and management system (moldboardplowed cotton, no-till cotton with wheat cover crop, and rotationally grazed perennial pasture) on SCI. Counties with the highest cotton land area in each of the CMZ-state regions were selected for simulation. Mean county-level yield of cotton was used, and irrigation level was based on extent of land area in cotton, as described earlier. Soil texture selected in each county was fine sandy loam (or sandy loam or very fine sandy loam), except for three counties in which a silt loam was the closest match. Climatic details of the 43 locations chosen (1961 to 1990 means posted on www.worldclimate.com) can be found in table 3. Mean yearly potential evapotranspiration (PET) was calculated from summing monthly values derived from temperature and latitude using the Thornthwaite equation, as described in Franzluebbers and Steiner (2002). Precipitation to potential evapotranspiration (P/PET) was considered an index of decomposition potential for a particular location since both temperature and precipitation varied.

Analysis of variance using the general linear model procedure of SAS v. 9.2 (SAS Institute Inc. Cary, North Carolina) was conducted to test for significance of difference $(p$ $\leq 0.05$ ) among crop rotations with and without slope as a covariate within each region and across regions in Analysis 1. Cropping systems were fixed effects and county observations were random effects within a region and across regions. Separate analyses were conducted for each region. Analysis 2 was conducted to determine the relative proportion of variation (i.e., the sums of squares) that could be attributed to soil texture ( 3 levels), land slope (3 levels), climatic condition (3 levels), and tillage management (3 levels). Analysis 3 was conducted to determine if land slope and management factors would be affected similarly by climatic condition, using linear regression along a $\mathrm{P} / \mathrm{PET}$ gradient $(p$ $\leq 0.05)$. 
Table 2

Climate, soil, and management conditions used in Analysis 2 with three land slopes ( $1 \%, 5 \%$, and 9\%).

\begin{tabular}{|c|c|c|c|c|c|}
\hline Management & Soil series & Sand $(\%)$ & Silt (\%) & Clay (\%) & Erodibility \\
\hline \multicolumn{6}{|c|}{ Central Rolling Plains, $\mathrm{CMZ}=48$ (Jackson County, Oklahoma) $-17.1^{\circ} \mathrm{C}, 645 \mathrm{~mm}$} \\
\hline Cotton, lister & Grandfield LS & 84 & 9 & 7 & 0.20 \\
\hline Cotton, no-till & La Casa SiCL & 20 & 49 & 31 & 0.37 \\
\hline \multicolumn{6}{|c|}{ Tennessee Valley, $\mathrm{CMZ}=63$ (Gibson County, Tennessee) $-14.2^{\circ} \mathrm{C}, 1,384 \mathrm{~mm}$} \\
\hline Cotton, fall chisel till & Grenada SiL & 3 & 83 & 14 & 0.49 \\
\hline Cotton, no-till, wheat cover crop, no-till & Lexington SiL & 15 & 64 & 21 & 0.49 \\
\hline \multicolumn{6}{|c|}{ Eastern Coastal Plain, $\mathrm{CMZ}=67$ (Colquitt County, Georgia) $-19.1^{\circ} \mathrm{C}, 1,280 \mathrm{~mm}$} \\
\hline Cotton, fall moldboard plow, subsoiler bedder & Albany S & 93 & 2 & 5 & 0.10 \\
\hline Cotton, spring chisel & Dothan LS & 86 & 4 & 10 & 0.15 \\
\hline Cotton, no-till, rye cover crop, no-till & Rains fSL & 67 & 20 & 12 & 0.24 \\
\hline
\end{tabular}

Notes: $\mathrm{fSL}=$ fine sandy loam. $\mathrm{L}=$ loam. $\mathrm{LS}=$ loamy sand. $\mathrm{S}=$ sand. $\mathrm{SiCL}=$ silty clay loam. $\mathrm{SiL}=$ silt loam. $\mathrm{CMZ}=$ crop management zone used in RUSLE2.

\section{Results and Discussion}

Effect of Management on Soil Conditioning Index (Analysis 1). Soil conditioning index within a region was always greater under the six conservation management systems than under conventional tillage cotton, as well as across regions $(\mathrm{SCI}=0.58 \pm 0.29[$ mean \pm standard deviation among 6 conservation systems $\times 10$ regions] vs. $-1.25 \pm 0.76$ [mean \pm standard deviation among 10 regions for CT]) (table 4). This difference was due to the very strong effect that tillage disturbance had on the ER and FO components of SCI (i.e., susceptibility of soil to erosion and stimulation of microbial activity in soil). In fact, RUSLE2 estimated soil erosion losses across all sites of $28.5 \mathrm{Mg} \mathrm{ha}^{-1} \mathrm{y}^{-1}\left(12.7 \mathrm{tn} \mathrm{ac}^{-1} \mathrm{yr}^{-1}\right.$ ) under conventional tillage cotton, $3.9 \pm 1.7$ $\mathrm{Mg} \mathrm{ha}{ }^{-1} \mathrm{y}^{-1}\left(1.7 \pm 0.8 \mathrm{tn} \mathrm{ac}^{-1} \mathrm{yr}^{-1}\right)$ under no-till cotton management systems (NT-c, NT-cc, NT-ccpc, NT-ccws, and NT-cchpc), and $1.3 \mathrm{Mg} \mathrm{ha}^{-1} \mathrm{y}^{-1}\left(0.6\right.$ tn $\left.\mathrm{ac}^{-1} \mathrm{yr}^{-1}\right)$ under perennial pasture. We included perennial pasture as a control conservation management system to compare with cotton production systems, expecting that it would have low soil erosion and high SCI. Indeed, SCI score was greater under perennial pasture than under all NT cotton production systems in each region, as well as across regions $(\mathrm{SCI}=1.04$ \pm 0.09 among 10 regions vs. SCI $=0.46 \pm$ 0.23 among 5 NT management systems $\times$ 10 regions) (table 4$)$.

Rates of soil erosion estimated in this analysis were similar to estimates obtained in several field studies in the southeastern United States. In southern Mississippi, soil loss was $18 \mathrm{Mg} \mathrm{ha}^{-1} \mathrm{y}^{-1}\left(8.0 \mathrm{tn} \mathrm{ac}^{-1} \mathrm{yr}^{-1}\right)$ under inversion tillage and $3 \pm 2 \mathrm{Mg} \mathrm{ha}^{-1} \mathrm{y}^{-1}$ $\left(1.3 \pm 0.9 \mathrm{tn} \mathrm{ac}^{-1} \mathrm{yr}^{-1}\right)$ under conservation tillage (McGregor et al. 1975). In northern Mississippi, soil loss was $28 \pm 29 \mathrm{Mg} \mathrm{ha}^{-1} \mathrm{y}^{-1}$ $\left(12.5 \pm 12.9 \mathrm{tn} \mathrm{ac}^{-1} \mathrm{yr}^{-1}\right)$ under inversion tillage, $13 \pm 15 \mathrm{Mg} \mathrm{ha}^{-1} \mathrm{y}^{-1}\left(5.8 \pm 6.7 \mathrm{tn} \mathrm{ac}^{-1}\right.$ $\mathrm{yr}^{-1}$ ) under cropping with grass buffers and terraces, and $0.1 \pm 0.1 \mathrm{Mg} \mathrm{ha}^{-1} \mathrm{y}^{-1}(<0.1 \mathrm{th}$ $\mathrm{ac}^{-1} \mathrm{yr}^{-1}$ ) under native forestland (Harden et al. 1999). In northern Georgia, soil loss was $23 \mathrm{Mg} \mathrm{ha}^{-1} \mathrm{y}^{-1}\left(10.3 \mathrm{tn} \mathrm{ac}^{-1} \mathrm{yr}^{-1}\right)$ under inversion tillage and $0.04 \mathrm{Mg} \mathrm{ha}^{-1} \mathrm{y}^{-1}\left(<0.1 \mathrm{tn} \mathrm{ac}^{-1}\right.$ $\mathrm{yr}^{-1}$ ) under conservation tillage (Endale et al 2000). In a Piedmont soil in North Carolina, soil loss was $75 \mathrm{Mg} \mathrm{ha}^{-1} \mathrm{y}^{-1}\left(33.5 \mathrm{tn} \mathrm{ac}^{-1} \mathrm{yr}^{-1}\right)$ under inversion tillage and $2.6 \mathrm{Mg} \mathrm{ha}^{-1} \mathrm{y}^{-1}$ (1.2 $\mathrm{tn} \mathrm{ac}^{-1} \mathrm{yr}^{-1}$ ) under no-till (Raczkowski et al. 2009).

Crop rotations of cotton with other crops (NT-ccpc, NT-ccws, and NT-cchpc) had greater SCI values than monoculture cotton (NT-c and NT-cc) in several western Cotton Belt regions (i.e., Desert Southwest, Southern High Plains, and Central Rolling Plains) (mean SCI scores of 0.76 vs. 0.65 , respectively), but equal SCI between systems in all other regions (mean SCI scores of 0.37 vs. 0.33 , respectively) (table 4 ). This regional difference may have been due to the positive effect of other crops on plant biomass production (i.e., positively affecting the $\mathrm{OM}$ component) compared with cotton in the arid western region and the negative effect of other crops on decomposition with planting disturbances (i.e., negatively affecting the FO component) in the wetter eastern region.

Almost universally, adding a winter cover crop to monoculture cotton had a positive effect on SCI scores (table 4). The response across all regions was for greater SCI with cover crop than without (mean SCI scores of 0.55 vs. 0.30 , respectively), but there were three regions in which the effect of cover crops was not significant on SCI (i.e., Lower Mississippi Valley, Tennessee Valley, and Southern Piedmont). Part of the reason for this regional difference was differential number of observations and random association of land slope interacting with the OM and FO components. Cover cropping generally has a small-negative planting disturbance with a no-till drill but a large-positive biomass input for soil improvement. Overall, these results are in accordance with synthesized literature results throughout the southeastern United States, in which no-till cropping with cover crops sequestered soil organic $\mathrm{C}$ at a rate of $0.55 \pm 0.06 \mathrm{Mg} \mathrm{C} \mathrm{ha}^{-1}$ $\mathrm{y}^{-1}\left(491 \pm 54 \mathrm{lb} \mathrm{C} \mathrm{ac} \mathrm{yr}^{-1} \mathrm{yr}^{-1}\right)$ compared with $0.30 \pm 0.05 \mathrm{Mg} \mathrm{C} \mathrm{ha}^{-1} \mathrm{y}^{-1}(268 \pm 45 \mathrm{lb} \mathrm{C}$ $\mathrm{ac}^{-1} \mathrm{yr}^{-1}$ ) for no-till cropping without cover crop (Franzluebbers 2010).

Crop rotations with cotton occurring once in three years tended to have lower SCI scores in most regions than when cotton was present twice in either four or five years (table 4).This effect was statistically significant across all data (mean SCI values of 0.42 vs. 0.52 , respectively) and in four different regions (i.e. Southern High Plains, South Texas, Central Rolling Plains, and Eastern Coastal Plain). In the case of the Southern High Plains region, inclusion of soybean in the rotation had a negative impact on SCI scores, despite soybean being no-till planted and double-cropped following wheat harvest. This result is curious since the crop rotation with peanut could also have been expected to have reduced SCI due to the mechanical digging of peanut. 
Table 3

Climatic characteristics of locations selected for Analysis 3 in association with two land slopes ( $1 \%$ and $5 \%$ ) and three management levels (conventional tillage cotton, no-till cotton, and rotationally grazed perennial pasture).

\begin{tabular}{|c|c|c|c|c|c|c|}
\hline Area & CMZ & Location & $\begin{array}{l}\text { Temperature } \\
\left({ }^{\circ} \mathrm{C}\right)\end{array}$ & $\begin{array}{l}\text { Precipitation } \\
(\mathrm{mm})\end{array}$ & $\begin{array}{l}\text { P/PET } \\
\left(\mathrm{mm} \mathrm{mm}^{-1}\right)\end{array}$ & $\begin{array}{l}\text { Soil } \\
\text { texture }\end{array}$ \\
\hline \multirow[t]{5}{*}{ Desert Southwest } & 23 & Dona Ana County, New Mexico & 15.9 & 238 & 0.28 & fSL \\
\hline & 33 & Pinal County, Arizona & 20.8 & 267 & 0.21 & fSL \\
\hline & 33 & Riverside County, California & 18.2 & 243 & 0.25 & $\mathrm{fSL}$ \\
\hline & 34 & Fresno County, California & 17.4 & 269 & 0.28 & fSL \\
\hline & 43 & El Paso County, Texas & 17.3 & 223 & 0.23 & fSL \\
\hline \multirow[t]{5}{*}{ Southern High Plains } & 5 & Haskell County, Kansas & 13.0 & 489 & 0.67 & fSL \\
\hline & 15 & Stevens County, Kansas & 12.8 & 470 & 0.66 & fSL \\
\hline & 15 & Carson County, Texas & 14.4 & 527 & 0.68 & fSL \\
\hline & 19 & Lea County, New Mexico & 16.6 & 426 & 0.47 & $\mathrm{fSL}$ \\
\hline & 19 & Dawson County, Texas & 16.2 & 471 & 0.53 & fSL \\
\hline \multirow[t]{6}{*}{ South Texas } & 37.1 & Bee County, Texas & 20.8 & 813 & 0.67 & $\mathrm{fSL}$ \\
\hline & 38.1 & Ellis County, Texas & 18.9 & 933 & 0.85 & $\mathrm{fSL}$ \\
\hline & 41 & Jim Wells County, Texas & 22.0 & 706 & 0.54 & fSL \\
\hline & 44 & Willacy County, Texas & 22.7 & 700 & 0.51 & fSL \\
\hline & 57 & Tom Green County., Texas & 18.2 & 519 & 0.50 & fSL \\
\hline & 58 & San Patricio County, Texas & 21.5 & 881 & 0.69 & $\mathrm{fSL}$ \\
\hline \multirow[t]{5}{*}{ Central Rolling Plains } & 40 & Sumner County, Kansas & 13.5 & 819 & 1.04 & fSL \\
\hline & 40 & Grant County, Oklahoma & 15.3 & 817 & 0.92 & $\mathrm{fSL}$ \\
\hline & 40 & Gray County, Texas & 13.7 & 532 & 0.72 & $\mathrm{fSL}$ \\
\hline & 48 & Jackson County, Oklahoma & 17.0 & 645 & 0.65 & fSL \\
\hline & 48 & Hall County, Texas & 15.8 & 521 & 0.59 & $\mathrm{fSL}$ \\
\hline \multirow[t]{3}{*}{ Lower Mississippi Valley } & 37 & Rapides County, Louisiana & 19.0 & 1,485 & 1.38 & fSL \\
\hline & 38 & Tensas County, Louisiana & 17.7 & 1,442 & 1.45 & vfSL \\
\hline & 38 & Yazoo County, Mississippi & 18.1 & 1,475 & 1.45 & SiL \\
\hline \multirow[t]{5}{*}{ Upper Mississippi Valley } & 17 & Mississippi County, Arkansas & 15.6 & 1,274 & 1.44 & fSL \\
\hline & 17 & Dunklin County, Missouri & 14.7 & 1,291 & 1.57 & $\mathrm{fSL}$ \\
\hline & 17 & Kay County, Oklahoma & 14.9 & 886 & 1.03 & fSL \\
\hline & 42 & Desha County, Arkansas & 16.4 & 1,306 & 1.44 & SiL \\
\hline & 42 & Coahoma County, Mississippi & 16.5 & 1,330 & 1.43 & vfSL \\
\hline \multirow[t]{3}{*}{ Central Coastal Plain } & 69 & Houston County, Alabama & 18.4 & 1,423 & 1.39 & fSL \\
\hline & 69 & Jackson County, Florida & 18.8 & 1,438 & 1.38 & fSL \\
\hline & 69 & Noxubee County, Mississippi & 16.8 & 1,500 & 1.62 & $\mathrm{fSL}$ \\
\hline \multirow[t]{3}{*}{ Tennessee Valley } & 63 & Limestone County, Alabama & 15.0 & 1,464 & 1.83 & fSL \\
\hline & 63 & Calhoun County, Mississippi & 16.7 & 1,364 & 1.49 & SiL \\
\hline & 63 & Haywood County, Tennessee & 15.5 & 1,334 & 1.55 & $\mathrm{fSL}$ \\
\hline \multirow[t]{4}{*}{ Eastern Coastal Plain } & 67 & Dooly County, Georgia & 18.9 & 1,146 & 1.08 & SL \\
\hline & 67 & Halifax County, North Carolina & 14.7 & 1,189 & 1.56 & fSL \\
\hline & 67 & Darlington County, South Carolina & 17.4 & 1,194 & 1.25 & SL \\
\hline & 67 & Southampton County, Virginia & 14.0 & 1,148 & 1.55 & fSL \\
\hline \multirow[t]{4}{*}{ Southern Piedmont } & 66 & Cherokee County, Alabama & 15.6 & 1,488 & 1.78 & fSL \\
\hline & 66 & Elbert County, Georgia & 15.5 & 1,248 & 1.54 & fSL \\
\hline & 66 & Stanly County, North Carolina & 15.5 & 1,215 & 1.48 & fSL \\
\hline & 66 & Chester County, South Carolina & 15.5 & 1,230 & 1.48 & $\mathrm{fSL}$ \\
\hline
\end{tabular}

Notes: CMZ = crop management zone used in RUSLE2. P/PET = precipitation ( $\mathrm{mm}$ ) divided by potential evapotranspiration (mm). fSL = fine sandy loam. $\mathrm{SiL}=$ silt loam. $\mathrm{SL}=$ sandy loam. $\mathrm{vfSL}=$ very fine sandy loam.

Timing of soil disturbance (i.e., early summer vs. fall) may have played a role. In the case of the Eastern Coastal Plain region, inclusion of soybean and peanut in a rotation had a negative impact on SCI scores compared with clover/grass hay and grass pasture in a rotation. This rotation effect was also significant in the Upper Mississippi Valley and South Texas regions. Across all data, mean SCI scores were lower in the cotton-cotton-peanut-corn rotation (0.43) than in the cotton-cottonclover/grass hay-grass pasture-corn rotation (0.60). It appears that variations in land slope, soil texture, and climatic conditions among regions may have affected the SCI response to various cotton rotations.
A factor causing some variation in significance of response of SCI was the unequal number of observations among regions (ranging from 22 in the Southern Piedmont to 130 in the Eastern Coastal Plain). However, excluding the Eastern Coastal Plain region, there were $38 \pm 11$ observations within a region. This quantity is generally a sufficient 
Table 4

Mean soil conditioning index values estimated for each of seven management systems in 10 regions of the Cotton Belt. One observation was made for each county represented in each region.

\begin{tabular}{|c|c|c|c|c|c|c|c|c|c|c|c|}
\hline Management system & \multicolumn{11}{|c|}{ Region of Cotton Belt } \\
\hline (1) CT cotton (CT-C) & -0.07 & -0.31 & -0.87 & -0.85 & -1.75 & -1.03 & -1.82 & -2.14 & -1.33 & -2.36 & -1.25 \\
\hline (2) NT cotton (NT-c) & 0.72 & 0.55 & 0.35 & 0.36 & 0.29 & 0.40 & 0.01 & 0.19 & 0.18 & -0.01 & 0.30 \\
\hline (3) NT cotton with cover (NT-cc) & 0.91 & 0.76 & 0.58 & 0.61 & 0.50 & 0.56 & 0.32 & 0.46 & 0.40 & 0.36 & 0.55 \\
\hline $\begin{array}{l}\text { (5) NT cotton-corn-wheat/soybean } \\
\text { with cover (NT-ccws) }\end{array}$ & 0.91 & 0.72 & 0.42 & 0.54 & 0.33 & 0.47 & 0.13 & 0.28 & 0.27 & 0.13 & 0.42 \\
\hline $\begin{array}{l}\text { (6) NT cotton-cotton-clover/grass } \\
\text { hay-grass pasture-corn with cover } \\
\text { (NT-cchpc) }\end{array}$ & 0.85 & 0.81 & 0.61 & 0.68 & 0.56 & 0.61 & 0.40 & 0.54 & 0.47 & 0.45 & 0.60 \\
\hline $\begin{array}{l}\text { Conservation vs. conventional: } \\
\text { (1) vs. ( } 2 \text { through } 7 \text { ) }\end{array}$ & $<0.001$ & $<0.001$ & $<0.001$ & $<0.001$ & $<0.001$ & $<0.001$ & $<0.001$ & $<0.001$ & $<0.001$ & $<0.001$ & $<0.001$ \\
\hline $\begin{array}{l}\text { Cropped vs. grass: } \\
\text { (2 through 6) vs. (7) }\end{array}$ & $<0.001$ & $<0.001$ & $<0.001$ & $<0.001$ & $<0.001$ & $<0.001$ & $<0.001$ & $<0.001$ & $<0.001$ & $<0.001$ & $<0.001$ \\
\hline $\begin{array}{l}\text { Monoculture vs. rotated cotton: } \\
\text { (2 and } 3 \text { ) vs. (4 through } 6)\end{array}$ & 0.004 & $<0.001$ & 0.39 & $<0.001$ & 0.92 & 0.63 & 0.55 & 0.79 & 0.19 & 0.72 & 0.01 \\
\hline $\begin{array}{l}\text { Cover vs. no cover: } \\
\text { (2) vs. (3) }\end{array}$ & $<0.001$ & $<0.001$ & $<0.001$ & $<0.001$ & 0.28 & 0.03 & 0.05 & 0.09 & $<0.001$ & 0.12 & $<0.001$ \\
\hline $\begin{array}{l}\text { Cotton } 1 \text { of } 3 \text { years vs. more often: } \\
\text { (5) vs. ( } 4 \text { and } 6)\end{array}$ & 0.15 & $<0.001$ & 0.01 & 0.04 & 0.48 & 0.34 & 0.28 & 0.42 & 0.02 & 0.44 & 0.002 \\
\hline $\begin{array}{l}\text { Cotton rotated with peanut vs. grass: } \\
\text { (4) vs. (6) }\end{array}$ & 0.40 & 0.92 & 0.007 & 0.16 & 0.23 & 0.02 & 0.09 & 0.06 & 0.002 & 0.17 & $<0.001$ \\
\hline
\end{tabular}

sampling size to determine normal distribution of a population of responses.

Effect of Slope on Soil Conditioning Index (Analysis 1). Slope of land was a somewhat random association with the procedure for soil selection within a county-level database in RUSLE2. The selection process appears to have effectively simulated the probability for cropping under various land slopes within a region, based on the resulting reasonable distribution of land slope within Cotton Belt regions (figure 2). We simply restricted slope selection to $\leq 15 \%$, since it was assumed unlikely to have cotton production on steeper slopes. All regions had a significantly large percentage of simulations with $\leq 2 \%$ slope $(61 \% \pm 22 \%$ among regions $)$. The Upper Mississippi Valley region had the lowest mean slope of $1.5 \%$, and the Southern Piedmont region had the largest mean slope of $5.5 \%$. The percentage of simulations with slope $\geq 5 \%$ tended to increase from western to eastern regions, wherein the six western regions had $7 \% \pm 6 \%$ of the simulations with land slope $\geq 5 \%$ and the four eastern regions had $30 \% \pm 10 \%$ of the simulations with land slope $\geq 5 \%$.

Slope of land was a significant covariate on SCI score for all management systems evaluated, although the magnitude of the slope effect varied among management systems The greatest effect of slope on SCI was for conventional tillage cotton, whereas the effect of slope on SCI was minimal for no-till cotton with cover crop (figure 3 ). With relatively level land, SCI scores could be expected to be near 0 even under conventional tillage cotton. However with increasing slope of land, SCI scores declined dramatically under conventional tillage cotton by 0.38 SCI units for every slope percentage increase. Surface residue cover and lack of disturbance with no-till management greatly subdued the negative effect of land slope on SCI scores. Linear regression of soil loss estimated with RUSLE2 upon slope of land resulted in expected soil loss as low as $1.5 \mathrm{Mg} \mathrm{ha}^{-1} \mathrm{y}^{-1}$ (0.7 tn $\left.\mathrm{ac}^{-1} \mathrm{yr}^{-1}\right)(0.5 \%$ slope) and as high as $154 \mathrm{Mg} \mathrm{ha}^{-1} \mathrm{y}^{-1}$ (69 tn $\left.\mathrm{ac}^{-1} \mathrm{yr}^{-1}\right)$ (15\% slope) with conventional tillage cotton and 0.4 to $11.2 \mathrm{Mg} \mathrm{ha}^{-1} \mathrm{y}^{-1}\left(0.2 \pm 5.0\right.$ tn $\left.\mathrm{ac}^{-1} \mathrm{yr}^{-1}\right)$ with no-till cotton and cover crop (data not shown). As expected, these results suggest that farms with steep slope are in greatest need of conservation practices to reduce soil erosion and increase SCI scores. However, these results also suggest that sloping land could be brought under crop cultivation without serious threat of soil loss and soil organic C decline, if appropriate conservation management approaches were adopted. Potentially, a significant amount of sloping land currently under perennial pastures in the southeastern United States could be developed into pasture-crop rotations with conservation tillage, resulting in greater quantity and diversity of crop production and likely minimal negative consequences on soil erosion and soil organic C content (Franzluebbers and Triplett 2006; 


\section{Figure 2}

Frequency distribution of sites within a region associated with increasing slope of land. $M=$ mean and $M d n=$ median.

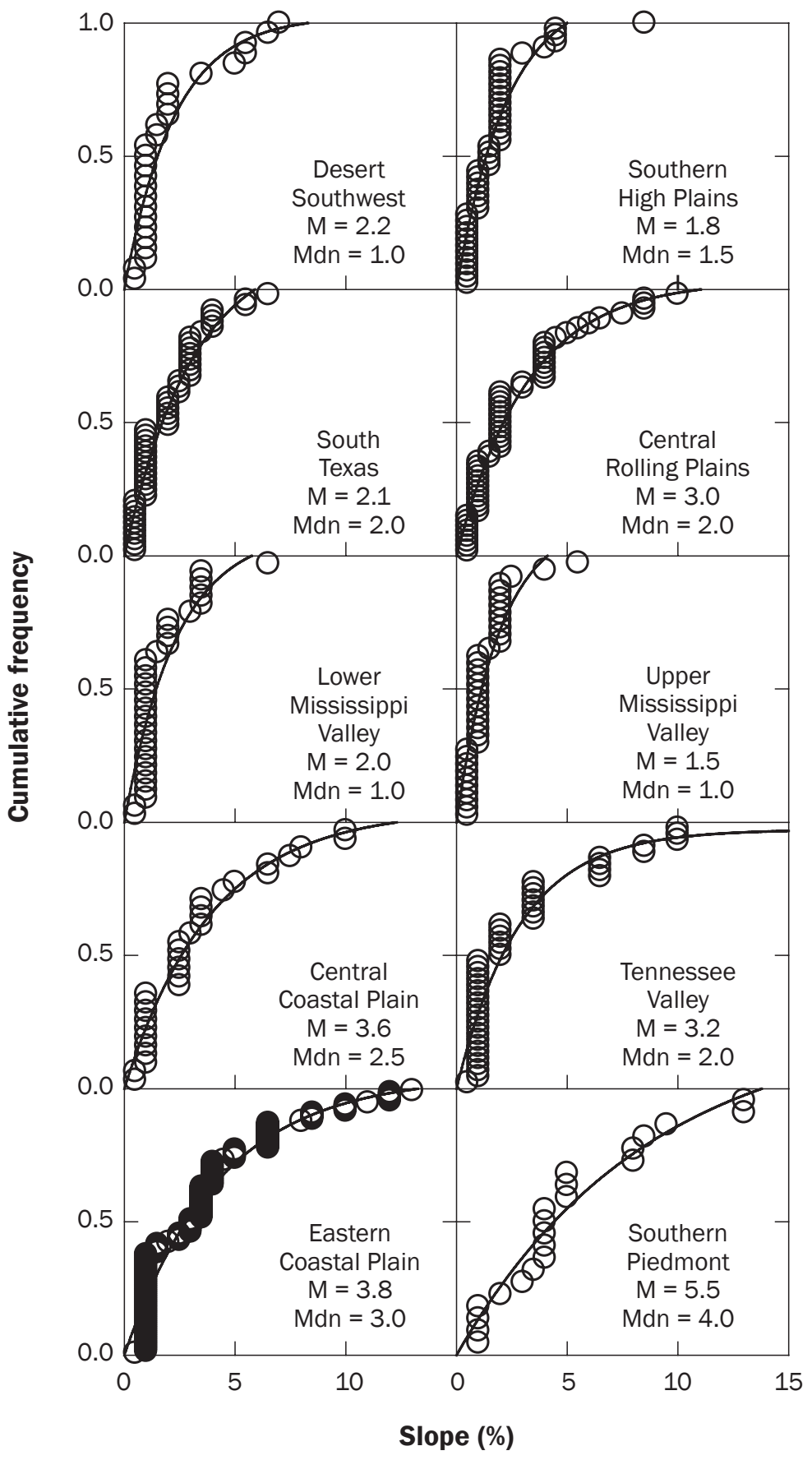

Franzluebbers 2007). Further research is needed to better understand the potential impacts of such a shift in management on sensitive lands.

In addition to slope of land affecting SCI, figure 4 illustrates how region (expressed climatically as $\mathrm{P} / \mathrm{PET}$ ) interacted with slope of land and management system. In figure $4 a$, SCI declined in increasingly wetter environments (i.e., increasing $\mathrm{P} / \mathrm{PET}$ ) under no-till management of cotton with or without cover crop but more so with greater slope. In addition, this graphic illustrates the interaction that occurred among $\mathrm{C}$ input with cover cropping, slope of land, and climatic condition, in which SCI was more similar in dry environments among management systems, but diverged greatly in wetter environments, depending upon management. On a broader scale, figure $4 \mathrm{~b}$ illustrates how conventional tillage had a dramatically negative effect on SCI with greater slope of land than with little slope, while slope had a minor effect on SCI under conservation management systems.

Relative Impacts of Texture, Slope, Climate, and Management on Soil Conditioning Index and Soil Loss (Analysis 2). Four factors with three levels per factor were evaluated for their relative contribution to variations in SCI and soil loss. Details of the factors and their levels are described in table 2. Variation in SCI was dominated by tillage management (46\%) and slope (26\%) and very little affected by climate $(7 \%)$ and soil texture (1\%). The contribution of two-way interactions to SCI variation followed the same pattern of influence, although only soil texture had little influence $(2 \%)$ compared with the other factors $(13 \% \pm 4 \%)$. This analysis suggests that tillage management decisions within a particular land slope class will have the greatest impact on SCI score. Mean SCI scores for conventional tillage systems (lister, fall chisel till, and fall moldboard plow) were -0.74 , -2.44 , and -4.22 for $1 \%, 5 \%$, and $9 \%$ slope, respectively. Mean SCI scores for reduced tillage systems (ridge till, spring chisel) were $-0.31,-1.32$, and -2.30 for $1 \%, 5 \%$, and $9 \%$ slope, respectively. Mean SCI scores for no-till systems were $0.40,0.22$, and 0.02 for $1 \%, 5 \%$, and $9 \%$ slope, respectively. Responses of SCI to tillage management and slope suggest that no-till management would be the only logical choice to preserve soil condition under a diversity of slope conditions, but that only under low slope conditions could soil condition be expected to increase, since $9 \%$ slope resulted in a SCI score near zero.

The influence of these four factors on soil loss predicted by RUSLE2 followed a slightly different pattern than that for SCI: tillage management (33\%), slope (33\%), climate $(6 \%)$, and soil texture $(2 \%)$. Like that for SCI, soil loss had larger two-way interaction contributions from management, slope, and climate $(17 \% \pm$ $5 \%)$ than from soil texture (3\%).

How individual crop phases affected the three components of SCI (i.e., OM, FO, and ER) was also investigated. Across three sites (Willacy County, Texas, with 3\% slope and 0.5 P/PET, Dooly County, Georgia, with 


\section{Figure 3}

(a) Response of soil conditioning index to slope of land in conventional and no-till cotton production and (b) frequency distribution of sites throughout the Cotton Belt associated with increasing slope of land.

(a)

No-till cotton with cover crop

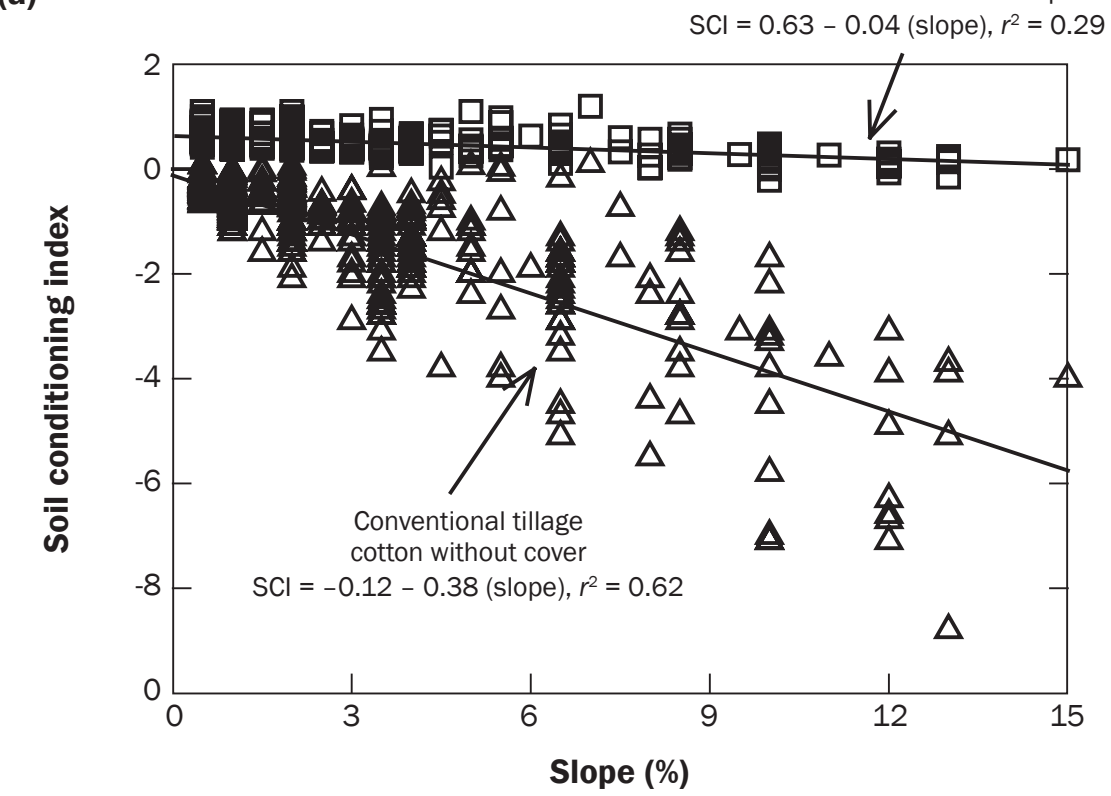

(b)

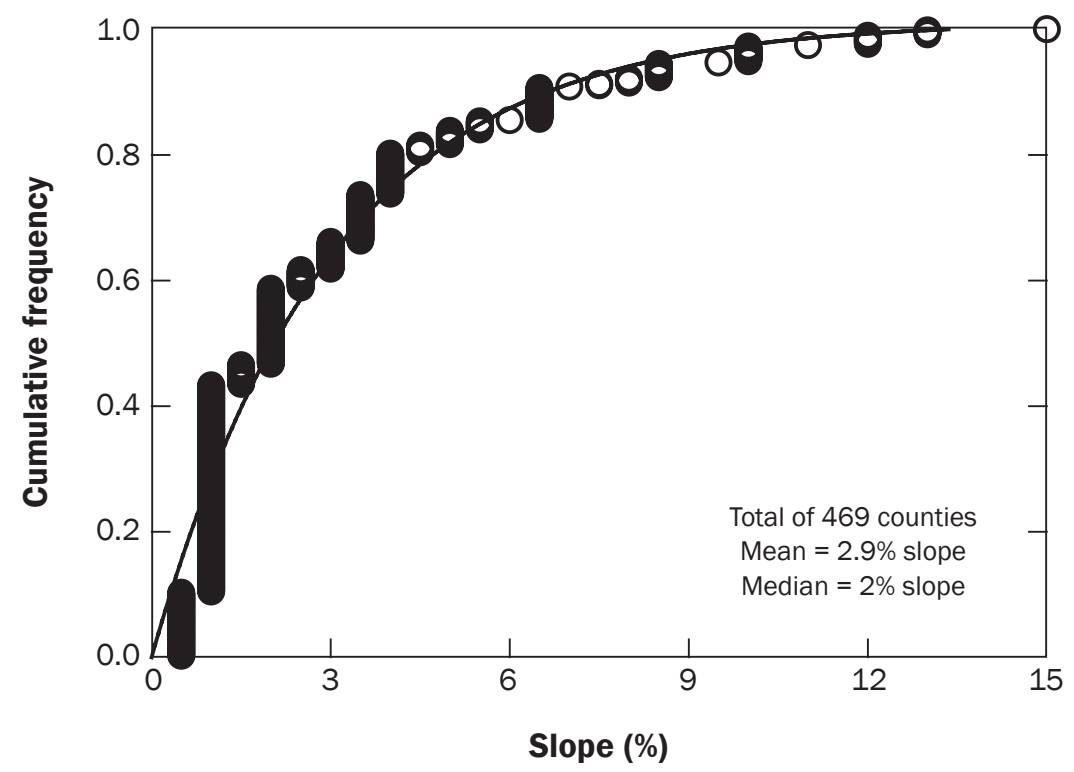

8.5\% slope and $1.1 \mathrm{P} / \mathrm{PET}$, and Dunklin County, Missouri, with $0.5 \%$ slope and 1.6 $\mathrm{P} / \mathrm{PET}$ ), the type of crop had a large impact on the OM component, no effect on the FO component, and a relatively mild effect on the ER component. The OM component was lowest with cotton $(-0.29 \pm 0.34)$, intermediate with peanut $(0.05 \pm 0.33)$, and highest with all other crop phases, including corn $(0.59 \pm 0.47)$, wheat/soybean double crop (0.38 \pm 0.45$)$, hayed pasture (0.72 $\pm 0.55)$, grazed pasture $(0.47 \pm 0.48)$, and rotationally grazed pasture $(1.25 \pm 0.52)$. The OM component predicts the input of organic matter from crop residues, as well as the decomposition of organic matter. The ER component was lowest with cotton $(-0.45 \pm 1.83)$, intermediate with peanut $(0.16 \pm 0.43)$, and highest with all other crop phases, including corn $(0.82 \pm 0.11)$, wheat/ soybean double crop $(0.65 \pm 0.19)$, hayed pasture $(0.87 \pm 0.07)$, grazed pasture $(0.95$ $\pm 0.02)$, and rotationally grazed pasture $(0.84$ \pm 0.10). High organic matter input with high-residue-producing crops appeared to be important for raising the OM component score, and continuous ground cover during a long growing season appeared to be important for raising the ER component score.

Interaction of Climate, Slope, and Management on Soil Conditioning Index (Analysis 3). To get a more robust estimate of the influence of climate on SCI response, we selected 43 sites to obtain a range of mean annual temperature and precipitation conditions throughout the Cotton Belt (table 3; figure 5). Potential evapotranspiration was derived from the Thornthwaite equation, which is closely aligned with mean annual temperature but not with precipitation (figure 5).

Soil conditioning index was always negatively related with increasing ratio of $\mathrm{P} / \mathrm{PET}$ (figure 6). This negative relationship was due to significantly negative influences from both OM and ER components within SCI (data not shown). The OM component was likely due to the strong influence of increasing precipitation that stimulates soil organic matter decomposition. However, the extent of decline with $\mathrm{P} / \mathrm{PET}$ was highly dependent on slope, more so under moldboard-plowed cotton than with no-till cotton. With greater land slope under conventional tillage, SCI score declined much more with increasing P/PET; a function of the ER component that was likely due to the increasingly greater threat of soil erosion that would wash away soil organic matter-enriched surface soil. From the regression lines plotted in figure 6 , SCI with $1 \%$ slope under driest conditions $(\mathrm{P} / \mathrm{PET}=0.25)$ would be -0.15 under moldboard-plowed cotton, 0.80 under no-till cotton with wheat cover crop, and 1.12 under rotationally grazed perennial pasture. These same values under wettest condition $(\mathrm{P} /$ PET $=1.75)$ would be $-0.85,0.42$, and 0.98 , respectively. Predicted soil loss from RUSLE2 increased linearly with increasing $\mathrm{P} / \mathrm{PET}$ under all management conditions (data not shown) but was most dramatic under moldboard-plowed cotton with $5 \%$ slope of land (13.4 $\mathrm{Mg} \mathrm{ha}^{-1} \mathrm{y}^{-1}\left[6.0 \mathrm{tn} \mathrm{ac}^{-1} \mathrm{y}^{-1}\right]$ at P/PET of $0.5 \mathrm{~mm} \mathrm{~mm}^{-1}, 36.3 \mathrm{Mg} \mathrm{ha}^{-1} \mathrm{y}^{-1}$ [16.2 $\mathrm{tn}$ $\mathrm{ac}^{-1} \mathrm{yr}^{-1}$ ] at P/PET of $1.0 \mathrm{~mm} \mathrm{~mm}^{-1}$, and 59.2 $\mathrm{Mg} \mathrm{ha}^{-1} \mathrm{y}^{-1}\left[26.4 \mathrm{tn} \mathrm{ac}^{-1} \mathrm{yr}^{-1}\right]$ at P/PET of 1.5

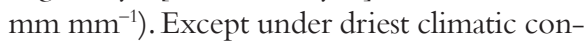




\section{Figure 4}

Response of soil conditioning index to (a) no-till management of cotton with and without cover crop and under two extremes of land slope and to (b) conventional tillage cotton, no-till cotton, and perennial pasture systems under two extremes of land slope. CT is conventional tillage and NT is no-till.

(a)

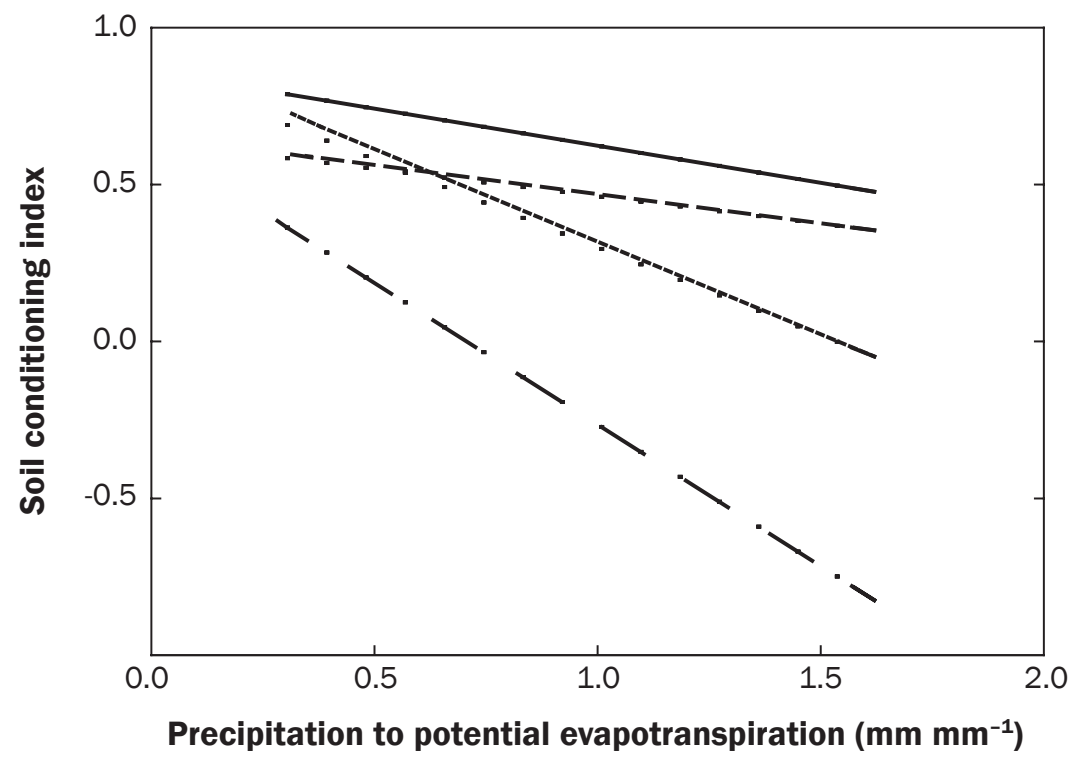

Legend

NT cotton/wheat cover, 0.5\% slope

- - - NT cotton - no cover, 0.5\% slope

NT cotton/wheat cover, $15 \%$ slope

- - NT cotton - no cover, 15\% slope

(b)

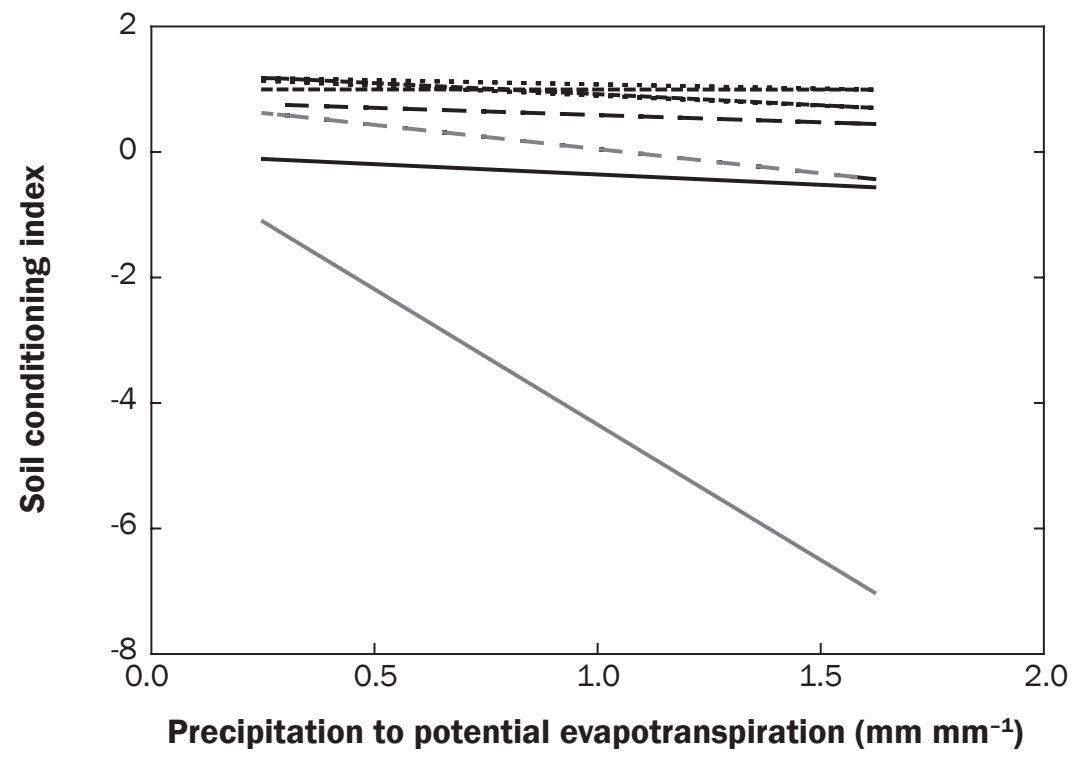

Legend

$$
\begin{aligned}
& ---- \text { Grass, both slopes } \\
& -- \text { NT, 0.5\% slope } \\
& --- \text { NT, } 15 \% \text { slope }
\end{aligned}
$$

ditions, these levels exceed the tolerable limit of soil loss (generally $11.2 \mathrm{Mg} \mathrm{ha}^{-1} \mathrm{y}^{-1}[5 \mathrm{tn}$ $\left.\left.\mathrm{ac}^{-1} \mathrm{yr}^{-1}\right]\right)$, and therefore, are an indication of (1) the great need for additional soil conservation measures if moldboard plowing were to be required for a particular management system or (2) the importance of limiting the use of moldboard plowing to landscape positions only with level land (i.e., with minimal risk of soil erosion) and increasing the input of biomass via conservation rotations, cover crops, and perennials.

Relating Soil Conditioning Index to Soil Organic Carbon Sequestration. A linear relationship between SCI and soil organic C sequestration was developed from 130 observations across 31 field studies throughout the southeastern United States-soil organic C sequestration $\left(\mathrm{Mg} \mathrm{C} \mathrm{ha}{ }^{-1} \mathrm{y}^{-1}\right)=0.25 \pm \mathrm{SCI}$, with a standard error of the coefficient of 0.04 $\mathrm{MgC} \mathrm{ha}{ }^{-1} \mathrm{y}^{-1} \mathrm{SCl}^{-1}\left(36 \mathrm{lb} \mathrm{Cac}^{-1} \mathrm{yr}^{-1} \mathrm{SCl}^{-1}\right)$ (Franzluebbers et al. 2011a). Although SCI considers soil changes in the 0 to $10 \mathrm{~cm}(0$ to 4 in) depth and the calibration was established under conditions of variable depth (i.e., 20.4 $\pm 5.1 \mathrm{~cm}[8 \pm 2 \mathrm{in}])$, there was congruence between these two procedures because the vast majority of changes in soil organic $\mathrm{C}$ of the southeastern United States occur within the surface 0 to $10 \mathrm{~cm}$ depth (Franzluebbers 2010) and the calibration was on an area basis and not on a gravimetric basis. Transforming mean SCI scores across regions to soil organic $\mathrm{C}$ sequestration, therefore, would result in estimates of $-0.31 \pm 0.19 \mathrm{MgC} \mathrm{ha}{ }^{-1} \mathrm{y}^{-1}$ $\left(-280 \pm 170 \mathrm{lb} \mathrm{C} \mathrm{ac}^{-1} \mathrm{yr}^{-1}\right)$ under conventionally tilled cotton, $0.12 \pm 0.06 \mathrm{Mg} \mathrm{C} \mathrm{ha}^{-1}$ $\mathrm{y}^{-1}\left(103 \pm 52 \mathrm{lb} \mathrm{C} \mathrm{ac}^{-1} \mathrm{yr}^{-1}\right)$ under various notill crop rotations, and $0.26 \pm 0.02 \mathrm{Mg} \mathrm{C}^{-1}$ $\mathrm{y}^{-1}\left(231 \pm 20 \mathrm{lb} \mathrm{C} \mathrm{ac}^{-1} \mathrm{yr}^{-1}\right)$ under perennial pasture (mean \pm standard deviation among 10 regions). If comparative estimates of soil organic C sequestration were calculated (i.e., taking the difference in soil organic $\mathrm{C}$ sequestration between that of no-till and conventional tillage, such as often considered in single point-in-time estimates comparing two systems [Franzluebbers and Steiner 2002]), then soil organic $\mathrm{C}$ sequestration would be $0.39 \pm 0.14 \mathrm{Mg} \mathrm{C}^{-1} \mathrm{ha}^{-1}(348 \pm 125 \mathrm{lb} \mathrm{C}$ $\left.\mathrm{ac}^{-1} \mathrm{yr}^{-1}\right)$ under no-till cotton without cover cropping compared with conventional tillage and $0.45 \pm 0.15 \mathrm{Mg} \mathrm{C} \mathrm{ha}^{-1} \mathrm{y}^{-1}(402 \pm 134 \mathrm{lb}$ $\left.\mathrm{C} \mathrm{ac}{ }^{-1} \mathrm{yr}^{-1}\right)$ under no-till cotton with cover cropping compared with conventional tillage. Similar calculations would be $0.43 \pm 0.14 \mathrm{Mg}$ $\mathrm{C} \mathrm{ha}^{-1} \mathrm{y}^{-1}\left(384 \pm 125 \mathrm{lb} \mathrm{C} \mathrm{ac}^{-1} \mathrm{yr}^{-1}\right)$ under the 


\section{Figure 5}

Relationship of mean annual potential evapotranspiration (PET) to (a) mean annual temperature (MAT) and to (b) mean annual precipitation.

(a)

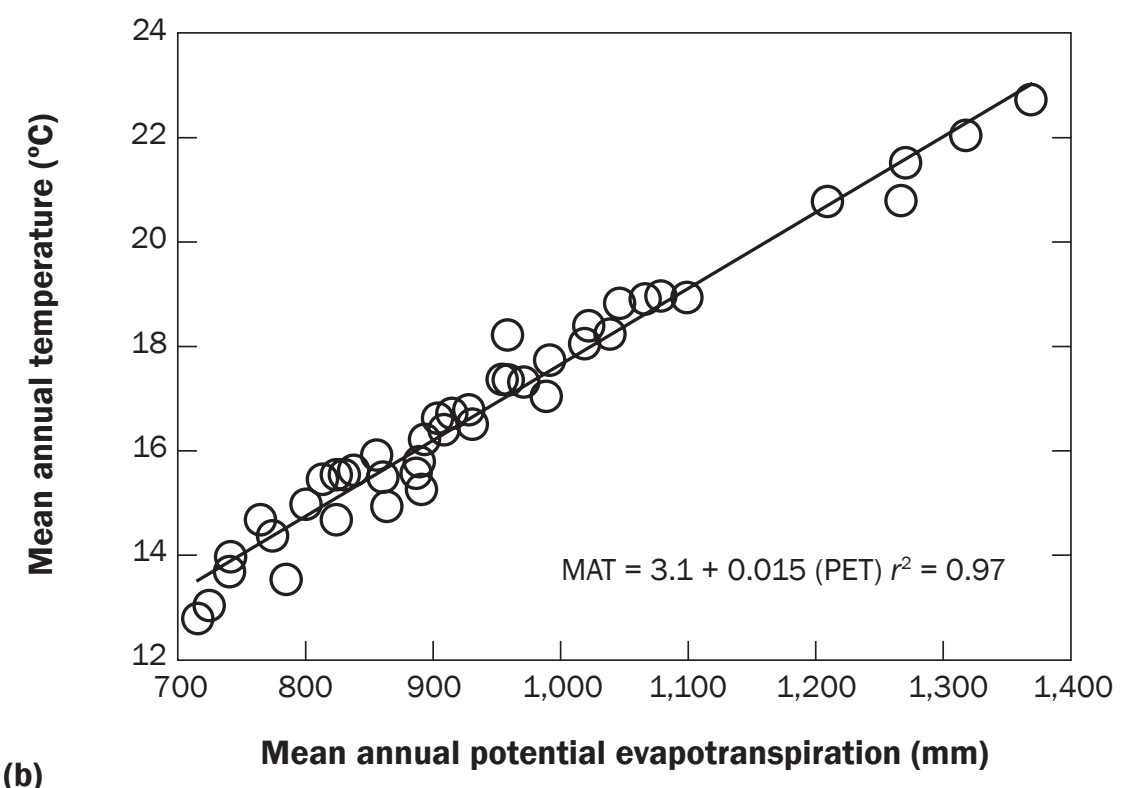

(b)

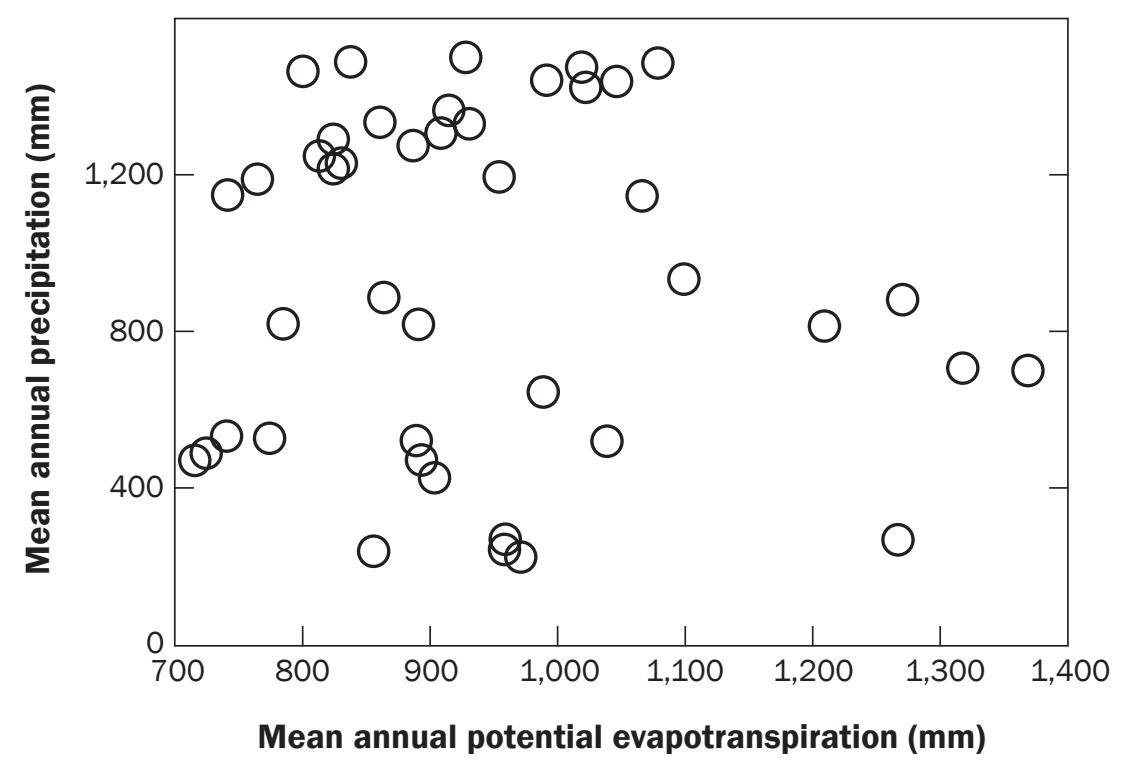

three other no-till crop rotations and $0.57 \pm$ $0.18 \mathrm{Mg} \mathrm{C} \mathrm{ha} \mathrm{y}^{-1}\left(509 \pm 161 \mathrm{lb} \mathrm{C} \mathrm{ac}^{-1} \mathrm{yr}^{-1}\right)$ under perennial pasture.

Both the independent $(0.12 \pm 0.06 \mathrm{Mg}$ $\mathrm{C} \mathrm{ha} \mathrm{h}^{-1} \mathrm{y}^{-1}\left[103 \pm 52 \mathrm{lb} \mathrm{C} \mathrm{ac}^{-1} \mathrm{yr}^{-1}\right]$ among no-till systems) and comparative (0.43 \pm $0.14 \mathrm{Mg} \mathrm{C} \mathrm{ha} \mathrm{y}^{-1}\left[384 \pm 125 \mathrm{lb} \mathrm{C} \mathrm{ac}{ }^{-1}\right.$ $\mathrm{yr}^{-1}$ ] among no-till systems) estimates of soil organic C sequestration derived from SCI simulation appear to be reasonable based on previously published estimates from vari- ous syntheses of field studies. For example, soil organic $\mathrm{C}$ sequestration with conservation tillage systems has been estimated as $0.27 \mathrm{Mg} \mathrm{C} \mathrm{ha}^{-1} \mathrm{y}^{-1}\left(241 \mathrm{lb} \mathrm{C} \mathrm{ac}^{-1} \mathrm{yr}^{-1}\right)$ in the northwestern United States and western Canada (Liebig et al. 2005), 0.30 Mg C ha ${ }^{-1}$ $\mathrm{y}^{-1}\left(268 \mathrm{lb} \mathrm{C} \mathrm{ac}^{-1} \mathrm{yr}^{-1}\right)$ in the southwestern United States (Martens et al. 2005), $0.48 \mathrm{Mg}$ $\mathrm{C} \mathrm{ha}^{-1} \mathrm{y}^{-1}\left(429 \mathrm{lb} \mathrm{C} \mathrm{ac} \mathrm{yr}^{-1}\right)$ in the central United States (Johnson et al. 2005), 0.55 $\mathrm{Mg} \mathrm{C} \mathrm{ha} \mathrm{y}^{-1} \mathrm{y}^{-1}\left(491 \mathrm{lb} \mathrm{C} \mathrm{ac}^{-1} \mathrm{yr}^{-1}\right)$ with cover cropping in the southeastern United States (Franzluebbers 2010), and $0.57 \pm 0.14 \mathrm{MgC}$ $\mathrm{ha}^{-1} \mathrm{y}^{-1}\left(509 \pm 125 \mathrm{lb} \mathrm{C} \mathrm{ac}^{-1} \mathrm{yr}^{-1}\right)$ from data around the world (West and Post 2002). In eastern Canada, soil organic $\mathrm{C}$ sequestration with conservation tillage compared with conventional tillage was estimated as -0.07 $\mathrm{Mg} \mathrm{C} \mathrm{ha} \mathrm{y}^{-1} \mathrm{y}^{-1}\left(-63 \mathrm{lb} \mathrm{C} \mathrm{ac}^{-1} \mathrm{yr}^{-1}\right.$ ) (Gregorich et al. 2005).

The independent estimate of soil organic $\mathrm{C}$ sequestration under perennial pasture $(0.26$ $\pm 0.02 \mathrm{MgC} \mathrm{ha} \mathrm{y}^{-1} \mathrm{y}^{-1}\left[231 \pm 20 \mathrm{lb} \mathrm{C} \mathrm{ac}^{-1}\right.$ $\mathrm{yr}^{-1}$ ] among regions) appears to be low, but the comparative estimate $(0.57 \pm 0.18 \mathrm{MgC}$ $\mathrm{ha}^{-1} \mathrm{y}^{-1}\left[509 \pm 161 \mathrm{lb} \mathrm{C} \mathrm{ac} \mathrm{yr}^{-1}\right]$ among regions) appears to be at the lower level of values reported in the literature. Establishment of perennial pastures resulted in soil organic C sequestration of $0.84 \pm 0.11 \mathrm{Mg} \mathrm{Cha}^{-1} \mathrm{y}^{-1}$ $\left(750 \pm 98 \mathrm{lb} \mathrm{C} \mathrm{ac}^{-1} \mathrm{yr}^{-1}\right)$ among 35 observations throughout the southeastern United States (Franzluebbers 2010). In a survey of pastures in Virginia, soil organic C sequestration was estimated at $0.61 \mathrm{MgC} \mathrm{ha}^{-1} \mathrm{y}^{-1}(545$ $\left.\mathrm{lb} \mathrm{C} \mathrm{ac} \mathrm{yr}^{-1}\right)$ under management-intensive grazing compared with continuous grazing (Conant et al. 2003).

It is possible that a nonlinear relationship between SCI and soil organic C sequestration could also be appropriately developed. Some previous work has indicated such nonlinearity among these variables. Abrahamson et al. (2007) presented a diagram describing this possibility between SCI and EPIC-modeled soil organic $\mathrm{C}$ sequestration. The shape of a nonlinear relationship was also similar in an independent analysis of SCI related to soil organic C derived from a 4-year field study with different tillage types and frequencies (Franzluebbers et al. 2011a). In both of these cases, soil organic C increased much more sharply with positive SCI scores than when SCI scores were negative. The linear relationship between SCI and soil organic C sequestration was developed from a dataset of SCI scores mostly within a range of -2.1 to 0.6 , and therefore, further research is needed to relate soil organic $\mathrm{C}$ from field studies in conservation management systems with SCI scores $\geq 0.5$. Based on the results reported in table 4, such high SCI scores and associated soil organic $\mathrm{C}$ sequestration estimates will likely have to be assessed from field studies with perennial pastures or pasture-crop rotations in the eastern part of the Cotton Belt and from a diversity of no-till cropping sequences in the western part of the Cotton Belt. 


\section{Figure 6}

Response of soil conditioning index $(\mathrm{SCl})$ to a climate gradient of precipitation to potential evapotranspiration (P/PET) as affected by management and slope of land: (a) moldboardplowed cotton on $1 \%$ slope, (b) moldboard-plowed cotton on $5 \%$ slope, (c) no-till cotton with wheat cover crop on $1 \%$ slope, (d) no-till cotton with wheat cover crop on $5 \%$ slope, (e) rotationally grazed perennial pasture on $1 \%$ slope, and (f) rotationally grazed perennial pasture on $5 \%$ slope.

(a)

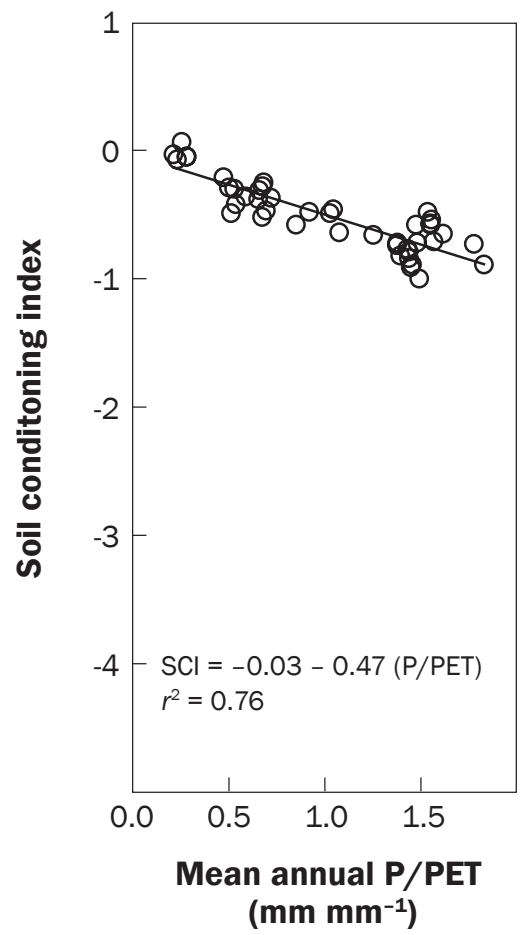

(c)

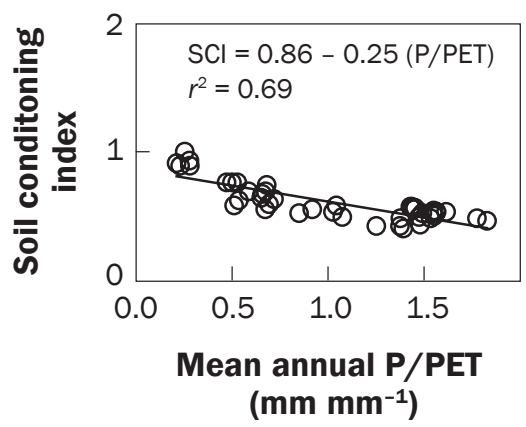

(e)

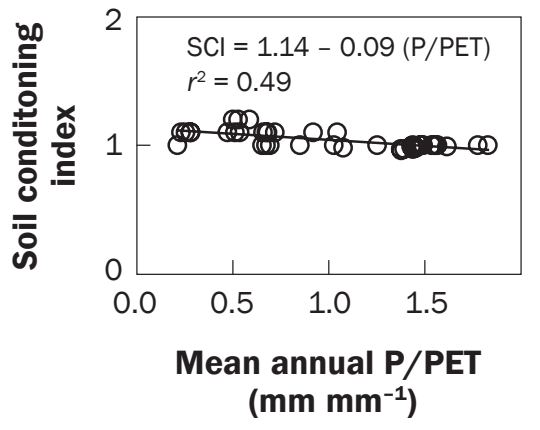

(b)

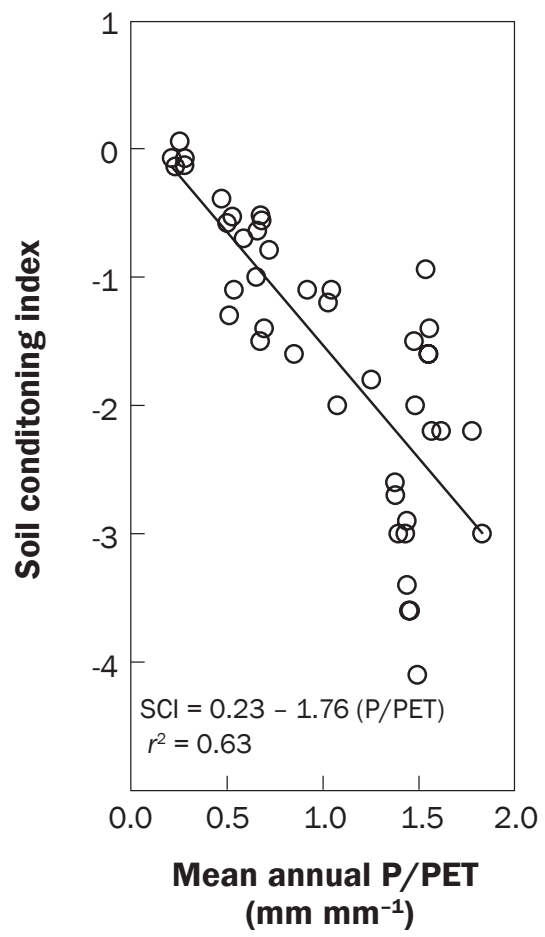

(d)

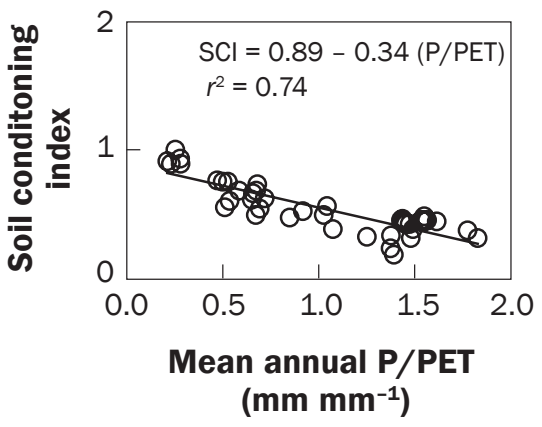

(f)

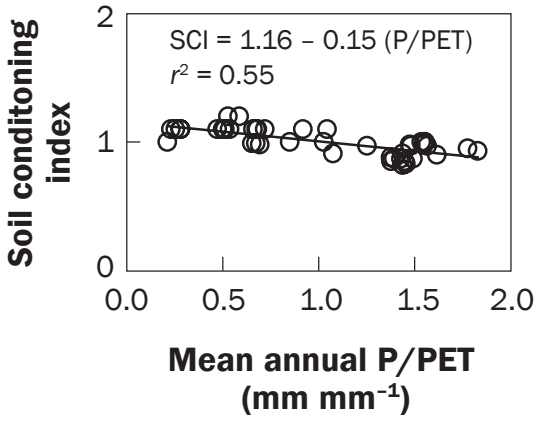

\section{Summary and Conclusions}

Using the recently calibrated soil conditioning index (SCI) in the RUSLE2 model, soil organic C was predicted to decline with conventional tillage in most regions of the Cotton Belt, except the Desert Southwest region. Any decision to continue farming with conventional tillage is also risky for soil loss from erosion on all but the flattest parcels of land. Soil organic C was predicted to increase (modestly to significantly) using a variety of crop sequences with no-till management in all regions of the Cotton Belt. Adding winter cover crops to the crop sequence was beneficial to organic matter input and subsequent estimate of soil organic C sequestration. Taking the difference between conservation management system and conventional tillage cotton, soil organic C sequestration was $0.39 \pm 0.14 \mathrm{Mg}$ $\mathrm{C} \mathrm{ha}^{-1} \mathrm{y}^{-1}\left(\left[348 \pm 125 \mathrm{lb} \mathrm{C} \mathrm{ac}^{-1} \mathrm{yr}^{-1}\right]\right.$ mean \pm standard deviation among 10 regions) under no-till cotton without cover cropping, 0.45 $\pm 0.15 \mathrm{Mg} \mathrm{C} \mathrm{ha}^{-1} \mathrm{y}^{-1}\left(402 \pm 134 \mathrm{lb} \mathrm{C} \mathrm{ac}^{-1}\right.$ $\left.\mathrm{yr}^{-1}\right)$ under no-till cotton with cover cropping, $0.43 \pm 0.14 \mathrm{MgC} \mathrm{ha}^{-1} \mathrm{y}^{-1}(384 \pm 125$ lb C ac $\mathrm{yr}^{-1}$ ) under the three other no-till crop rotations, and $0.57 \pm 0.18 \mathrm{Mg} \mathrm{C}^{-1}$ $\mathrm{y}^{-1}\left(509 \pm 161 \mathrm{lb} \mathrm{C} \mathrm{ac}^{-1} \mathrm{yr}^{-1}\right)$ under perennial pasture. Simulations were most sensitive to management and slope variations and much less affected by climate and soil textural variations. These results have important implications for the sustainable management of the 4.2 million ha (10.4 million ac) of cotton land in the southern United States.

\section{Acknowledgements}

This research was conducted as part of the Greenhouse Gas Reduction through Agricultural Carbon Enhancement network (GRACEnet) project of the USDA Agricultural Research Service. We appreciate the financial support of Cotton Incorporated under Agreement No. 05-712.

\section{References}

Abrahamson, D.A., H.J. Causarano, J.R. Williams, M.L. Norfleet, and A.J. Franzluebbers. 2009. Predicting soil organic carbon sequestration in the southeastern United States with EPIC and the soil conditioning index. Journal of Soil and Water Conservation 64(2):134-144, doi:10.2489/jswc.64.2.134.

Abrahamson, D.A., M.L. Norfleet, H.J. Causarano, J.R. Williams, J.N. Shaw, and A.J. Franzluebbers. 2007. Effectiveness of the soil conditioning index as a carbon management tool in the southeastern USA based on comparison with EPIC. Journal of Soil and Water Conservation 62(2):94-102. 
Conant, R.T., J. Six, and K. Paustian. 2003. Land use effects on soil carbon fractions in the southeastern United States. I. Management-intensive versus extensive grazing. Biology and Fertility of Soils 38:386-392.

Du, Z., T. Ren, and C. Hu. 2010. Tillage and residue removal effects on soil carbon and nitrogen storage in the North China Plain. Soil Science Society of America Journal 74(1):196-202.

Endale, D.M., H.H. Schomberg, and J.L. Steiner. 2000. Longterm sediment yield and mitigation in a small Southern Piedmont watershed. International Journal of Sediment Research 14:60-68.

Ernst, O., and G. Siri-Prieto. 2009. Impact of perennial pasture and tillage systems on carbon input and soil quality indicators. Soil and Tillage Research 105(2):260-268.

Franzluebbers,A.J.2005.Soil organic carbon sequestration and agricultural greenhouse gas emissions in the southeastern USA. Soil and Tillage Research 83(1):120-147.

Franzluebbers, A.J. 2007. Integrated crop-livestock systems in the southeastern USA. Agronomy Journal 99(2):361-372.

Franzluebbers, A.J. 2010. Achieving soil organic carbon sequestration with conservation agricultural systems in the southeastern United States. Soil Science Society of America Journal 74(2):347-357.

Franzluebbers, A.J., H.J. Causarano, and M.L. Norfleet. 2011a. Calibration of the soil conditioning index (SCI) to soil organic carbon in the southeastern USA. Plant and Soil 338:223-232.

Franzluebbers, A.J., H.J. Causarano, and M.L. Norfleet. 2011b. Soil conditioning index (SCI) and soil organic carbon in the Midwest and southeastern USA. Journal of Soil and Water Conservation 66(3):178-182, doi:10.2489/jswc.66.3.178.

Franzluebbers, A.J., F.M. Hons, and D.A. Zuberer. 1998. In situ and potential $\mathrm{CO} 2$ evolution from a Fluventic Ustochrept in southcentral Texas as affected by tillage and cropping intensity. Soil and Tillage Research 47(3-4):303-308.

Franzluebbers, A.J., G.W. Langdale, and H.H. Schomberg. 1999. Soil carbon, nitrogen, and aggregation in response to type and frequency of tillage. Soil Science Society of America Journal 63(2):349-355.

Franzluebbers,A.J., and J.L.Steiner. 2002. Climatic influences on soil organic carbon storage with no tillage. In Agricultural Practices and Policies for Carbon Sequestration in Soil, 71-86. Boca Raton, FL: Lewis Publishers.

Franzluebbers, A.J., and J.A. Stuedemann. 2008. Early response of soil organic fractions to tillage and integrated crop-livestock production. Soil Science Society of America Journal 72(3):613-625.

Franzluebbers,A.J., and G.B.Triplett,Jr. 2006. Integrated croplivestock systems to conserve soil and water resources in the southeastern USA. In Proceedings of the 28th Southern Conservation Tillage Systems Conference, eds. R.C. Schwartz, R.L. Baumhardt, and J.M. Bell. Amarillo, TX, 26-28 June 2006, 2-12. Bushland, TX:
USDA-ARS Conservation and Production Research Laboratory, Report No. 06-1. http://www.ag.auburn. edu/auxiliary/nsdl/scasc/.

Gregorich, E.G., P. Rochette, A.J. VandenBygaart, and D.A. Angers. 2005. Greenhouse gas contributions of agricultural soils and potential mitigation practices in eastern Canada. Soil and Tillage Research 83(1):53-72.

Harden, J.W., J.M. Sharpe, W.J. Parton, D.S. Ojima, T.L. Fries, T.G. Huntington, and S.M. Dabney. 1999. Dynamic replacement and loss of soil carbon on eroding cropland. Global Biogeochemical Cycles 13:885-901.

Johnson, J.M.F., D.C. Reicosky, R.R. Allmaras, T.J. Sauer, R.T. Venterea, and C.J. Dell. 2005. Greenhouse gas contributions and mitigation potential of agriculture in the central USA. Soil and Tillage Research 83(1):73-94.

Liebig, M.A., J.A. Morgan, J.D. Reeder, B.H. Ellert, H.T. Gollany, and G.E. Schuman. 2005. Greenhouse gas contributions and mitigation potential of agricultural practices in northwestern USA and western Canada. Soil and Tillage Research 83(1):25-52.

Madejon, E., J.M. Murillo, F. Moreno, M.V. Lopez, J.L. Arrue, J. Alvaro-Fuentes, and C. Cantero. 2009. Effect of long-term conservation tillage on soil biochemical properties in Mediterranean Spanish areas. Soil and Tillage Research 105(1):55-62.

Martens, D.A., W. Emmerich, J.E.T. McLain, and T.N. Johnsen. 2005. Atmospheric carbon mitigation potential of agricultural management in the southwestern USA Soil and Tillage Research 83(1):95-119.

McGregor, K.C., J.D. Greer, and G.E. Gurley. 1975. Erosion control with no-tillage cropping practice. Transactions of the American Society of Agricultural Engineers 18:918-920.

Novak, J.M., J.R. Frederick, P.J. Bauer, and D.W.Watts. 2009 Rebuilding organic carbon contents in Coastal Plain soils using conservation tillage systems. Soil Science Society of America Journal 73(2):622-629.

Raczkowski, C.W., M.R. Reyes, G.B. Reddy, W.J. Busscher, and P.J. Bauer. 2009. Comparison of conventional and no-tillage corn and soybean production on runoff and erosion in the southeastern US Piedmont. Journal of Soil and Water Conservation 64(1):53-60, doi:10.2489/jswc.64.1.53.

Rhoton, F.E. 2002. Influence of time on soil response to notill practices. Soil Science Society of America Journal 64(2):700-709.

Sá, J.C.M., C.C. Cerri, R. Lal, W.A. Dick, M.C. Piccolo, and B.E. Feigl. 2009. Soil organic carbon and fertility interactions affected by tillage chronosequence in a Brazilian Oxisol. Soil and Tillage Research 104(1):56-64

Sainju, U.M., B.P. Singh, and W.F. Whitehead. 2002 Long-term effects of tillage, cover crops, and nitrogen fertilization on organic carbon and nitrogen concentrations in sandy loam soils in Georgia, USA. Soil and Tillage Research 63(2):167-179.

Salvo, L., J. Hernandez, and O. Ernst. 2010. Distribution of soil organic carbon in different size fractions, under pasture and crop rotations with conventional tillage and no-till systems. Soil and Tillage Research 109(2):116-122.

Spargo, J.T., M.M. Alley, R.F. Follett, and J.V. Wallace. 2008. Soil carbon sequestration with continuous notill management of grain cropping systems in the Virginia Coastal Plain. Soil and Tillage Research 100(1-2):133-140.

Studdert, G.A., H.E. Echeverria, and E.M. Casanovas. 1997. Crop-pasture rotation for sustaining the quality and productivity of a Typic Argiudoll. Soil Science Society of America Journal 61(5):1466-1472.

Terra, J.A., D.W. Reeves, J.N. Shaw, and R.L. Raper. 2005. Impacts of landscape attributes on carbon sequestration during the transition from conventional to conservation management practices on a Coastal Plain field. Journal of Soil and Water Conservation 60(6):438-446.

USDA NASS (National Agricultural Statistics Service). 2002. Census of agriculture. http://www.nass.usda. gov/research/atlas02/.

USDA NASS. 2010. 2007 Census of Agriculture, Volume 1, United States summary and state data. http://www. agcensus.usda.gov/Publications/2007/Full_Report/ index.asp.

USDA NRCS (Natural Resources Conservation Service) 2003. Interpreting the soil conditioning index: A tool for measuring soil organic matter trends. Soil Quality Agronomy Technical Note 16. http://soils.usda.gov/sqi.

USDA NRCS. 2010. Official NRCS RUSLE2 program. Revised universal soil loss equation, Version 2. http:// fargo.nserl.purdue.edu/rusle2_dataweb/RUSLE2_ Index.htm.

VandenBygaart, A.J., E.G. Gregorich, and D.A. Angers. 2003. Influence of agricultural management on soil organic carbon: A compendium and assessment of Canadian studies. Canadian Journal of Soil Science 83(4):363-380.

West, T.O., and W.M. Post. 2002. Soil organic carbon sequestration rates by tillage and crop rotation: A global data analysis. Soil Science Society of America Journal 66(6):1930-1946. 